\title{
PENGEMBANGAN VIDEO PEMBELAJARAN FUNGSI KOMPOSISI SEBAGAI ALTERNATIF BAHAN AJAR UNTUK MENINGKATKAN KEMAMPUAN PENALARAN MATEMATIS
}

\author{
Ainia Rahmayanti ${ }^{*}$, Mochamad Abdul Basir ${ }^{2}$, Dyana Wijayanti ${ }^{3}$ \\ 1, 2,3Prodi Pendidikan Matematika FKP, Universitas Islam Sultan Agung \\ Jalan Raya Kaligawe Km 4, Semarang, Indonesia \\ e-mail: 1ainiar@std.unissula.ac.id; \\ Submitted: 12 Oktober 2020 \\ Revised: 3 Desember 2020 \\ Accepted: 5 Desember 2020 \\ corresponding author*
}

\begin{abstract}
Abstrak
Penelitian ini bertujuan untuk menghasilkan video pembelajaran pada materi fungsi komposisi sebagai alternative bahan ajar dan untuk mengetahui kelayakan video pembelajaran tersebut ditinjau dari presentase kevalidan oleh validator dan guru matematika, serta respon dan hasil tes siswa terhadap video pembelajaran fungsi komposisi yang dikembangkan. Metode penelitian menggunakan metode penelitian dan pengembangan atau Research and Development. Dengan langkah-langkah pengembangan diantaranya: (1) perencanaan (2) desain; dan (3) pengembangan. Subjek penelitian yang digunakan adalah beberapa siswa dalam kelompok kecil di Madrasah Aliyah Hasyim Ay'ari Bangsri Jepara. Hasil penelitian menunjukkan bahwa: (1) video pembelajaran pada materi fungsi komposisi sebagai alternatif bahan ajar; (2) video pembelajaran fungsi komposisi mendapatkan penilaian kelayakan berdasarkan dosen ahli dan guru matematika diperoleh hasil "Sangat Valid" dengan presentase rerata penilailan 82,4\% dari aspek materi, diperoleh hasil "Sangat Valid" dengan presentase rerata penilaian $87,2 \%$ dari aspek media, berdasarkan penilaian oleh siswa didapat respon siswa yang "Positif" dengan presentase rerata penilaian $70 \%$, dan hasil tes siswa dalam kelompok kecil mendapatkan rerata perolehan skor 69,6 yang masuk dalam kategori "Baik". Menunjukkan bahwa video pembelajaran fungsi komposisi sebagai alternatif bahan ajar dengan kemampuan penalaran layak digunakan dalam proses pembelajaran oleh guru dan siswa di SMA/MA.
\end{abstract}

Kata Kunci: fungsi komposisi, kemampuan penalaran, video pembelajaran

\section{DEVELOPMENT OF COMPOSITION FUNCTION VIDEO LEARNING AS AN ALTERNATIVE TEACHING MATERIALS IN IMPROVING MATHEMATICS REASONING ABILITY}

\begin{abstract}
This study aimed to produce instructional videos on the composition function material as an alternative teaching materials and to determine the appropriateness of the learning videos in terms of the validity percentage by the validator and mathematics teacher, as well as student responses and test results to the learning videos developed. The research method used research and development. Development steps including: (1) planning (2) design; and (3) development. The research subjects used were several students in small groups at Madrasah Aliyah Hssyim Ay'ari Bangsri Jepara. The data analysis technique used is descriptive qualitative. The results showed that: (1) instructional video in composition function materials as an alternative teaching materials, (2) the instructional video of the composition function received an appropriateness assessment based on expert lecturers and mathematics teachers, the result was "Very Valid" with a mean percentage of $82.4 \%$ of the material aspect, the result was "Very Valid" with a mean percentage of $87.2 \%$ of media aspect, based on the assessment by students, it was found that student responses were "positive" with a mean percentage of $70 \%$, and the test results of students in small groups got a mean score of 69.6 which into "Good" category. This shows that the instructional video in composition function materials as an alternative teaching material is suitable for use in the learning process by teachers and students in High School.
\end{abstract}

Keywords: composition function, reasoning ability, instructional video

\section{Pendahuluan}

Salah satu elemen penting dalam kemajuan bangsa adalah pendidikan, sebab pendidikan memiliki peran penting dalam membentuk dan mencetak generasi penerus bangsa. Pendidikan juga merupakan investasi jangka panjang dalam 
pengembangan sumber daya manusia yang memiliki nilai penting bagi kelangsungan peradaban manusia di dunia (Akbar \& Komarudin, 2018). Saat ini perkembangan teknologi komunikasi dan informasi yang semakin pesat mengharuskan bidang pendidikan beradaptasi dan melakukan pengembangan agar pendidikan selalu sejalan dengan kemajuan zaman.

Hal ini berarti dalam proses pendidikan perlu adanya pemanfaatan teknologi agar terjadi peningkatan kualitas dalam pendidikan. Terlebih pada kondisi yang terjadi sekarang ini yaitu adanya wabah Covid-19 yang melanda hampir seluruh dunia. Covid-19 merupakan penyakit infeksius yang disebabkan oleh virus yang menyerang sistem pernapasan, yang mana virus tersebut dapat menyebar secara langsung dan tidak langsung dari satu orang ke orang lainnya (Perlman, 2020). Di Indonesia, dalam upaya pencegahan percepatan penularan virus ini, proses pembelajaran yang semula dilakukan secara tatap muka di sekolah kemudian diberlakukan secara online atau pembelajaran jarak jauh.

Salah satu upaya pemanfaatan teknologi dalam pembelajaran pada situasi Covid-19 saat ini ialah penggunaan media pembelajaran berbasis multimedia, salah satunya adalah media video. Media video pembelajaran atau yang dapat disebut dengan media Audio-Visual adalah penggambaran atau visualisasi dari narasi materi pembelajaran yang dikemas dengan singkat (Arsyad, 2013). Dapat dikatakan bahwa video pembelajaran merupakan media pembelajaran yang memuat suara, gambar, dan teks yang dikemas dengan singkat, padat dan jelas (Purwanto \& Rizki, 2015). Pembelajaran menggunakan media video dinilai mampu meningkatkan keberhasilan siswa dalam belajar (Weeraratne \& Chin, 2018). Berdasarkan penelitian dari Lopes \& Soares (2016) video dapat menyajikan materi lebih baik dan jelas karena dapat mempresentasikan informasi dan pengetahuan yang tidak dapat dideskripsikan melalui bahan ajar teks maupun bahan ajar lainnya. Oleh karena itu, media video pembelajaran pada masa Covid-19 ini sangat mendukung untuk dikembangkan dalam proses kegiatan belajar mengajar, karena video pembelajaran dapat memuat visualisasi materi yang lebih baik sehingga siswa mampu memahami materi dengan jelas.

Salah satu bentuk video pembelajaran adalah video animasi yang memuat tulisan, gambar, animasi dan suara yang dapat membangun minat dan ketertarikan siswa pada konsep dan materi pembelajaran (Wardoyo \& Faqih Ma'arif, 2015). Software yang mendukung pembuatan video animasi adalah Sparkol VideoScribe. Dalam penyajiannya, media pembelajaran berbentuk video animasi ini dapat menekankan pada konsep Contextual Teaching Learning (CTL). Contextual Teaching Learning merupakan suatu proses pembelajaran holistik yang memiliki tujuan untuk membelajarkan siswa dalam memahami bahan ajar secara bermakna (meaningfull) yang dikaitkan dengan konteks kehidupan nyata (Hanafiah \& Suhana, 2010).

Salah satu materi pada pembelajaran matematika yang dapat divisualisasikan melalui video animasi salah satunya adalah materi Fungsi Komposisi. Fungsi komposisi merupakan penggabungan dua jenis fungsi atau lebih yang membentuk sebuah fungsi baru (Thomas, 1997). Beberapa penelitian sebelumnya mengungkapkan siswa mengalami kesulitan dalam memahami konsep dan prinsip pada materi fungsi komposisi (Rifai, 2016). Siswa juga kurang mampu dalam menentukan langkah-langkah penyelesaian permasalahan pada fungsi komposisi yang memuat beberapa operasi hitung dan aljabar yang mengakibatkan siswa kurang mampu dalam mengambil kesimpulan akhir dari soal-soal fungsi komposisi (Susanti \& Lestari, 2019). Seperti dalam menyelesaikan soal jika diketahui nilai komposisi fungsi (fog)(x) dan fungsi $\mathrm{g}(\mathrm{x})$ kemudian diminta untuk menentukan nilai fungsi $\mathrm{f}(\mathrm{x})$, siswa akan merasa kesulitan dalam melakukan permisalan dan perhitungan saat mensubstitusikan salah satu fungsi yang diketahui ke dalam fungsi lainnya (Kusumawati \& Aulia, 2018). Selain kesulitan pada penyelesaian aljabar fungsi komposisi, siswa juga kesulitan dalam menyelesaikan soal kontekstual. Kesulitan tersebut dikarenakan siswa kurang mampu dalam memilah informasiinformasi yang diperlukan dalam penyelesaian soal dan kurang mampu dalam mengidentifikasi apa yang sebenarnya ditanyakan dalam soal sehingga melakukan kesalahan dalam menentukan rumus fungsi komposisi yang harus digunakan (Utami, 2017).

Untuk dapat menyelesaikan permasalahan tersebut siswa harus dapat memahami informasi dari masalah yang diberikan terlebih dahulu kemudian siswa harus mampu mengidentifikasi masalah yang tepat dan menggarisbawahi informasi yang harus diketahui. Setelah mendapatkan informasi, siswa mencoba untuk merancang strategi yang digunakan dalam menyelesaikan masalah dengan kemampuan manipulasi matematika, lalu menyusun bukti terhadap solusi yang relevan dan mampu menarik kesimpulan dari permasalahan tersebut (Arfianto \& Hakim, 2019). Proses yang dilakukan siswa 
tersebut melibatkan kemampuan penalaran matematis. Pendekatan kontekstual dalam penyampaian bahan ajar dapat membantu siswa dalam meningkatkan kemampuan penalaran matematis (Fuadi et al., 2016).

Oleh karena itu, tujuan dalam penelitian ini adalah: (1) menghasilkan bahan ajar berbentuk video pembelajaran animasi pada materi fungsi komposisi, dan (2) mengetahui kelayakan bahan ajar berbentuk video pembelajaran animasi pada materi fungsi komposisi.

\section{Metode Penelitian}

Penelitian ini masuk dalam jenis penelitian dan pengembangan atau Research and
Development (R\&D) karena hasil penelitian berorientasi pada produk pembelajaran. Model pengembangan yang digunakan adalah desain pengembangan Alessi \& Trollip, (2001). Model pengembangan ini diterapkan karena dikhusukan untuk mengembangkan multimedia pembelajaran. Secara umum desain model pengembangan ini memiliki tiga atribut, diantaranya atribut standars; ongoing evaluation; dan project management; serta memiliki tiga fase pengembangan yaitu: (1) perencanaan; (2) desain; dan (3) pengembangan. Prosedur pengembangan dengan model desain pengembangan Alessi \& Trollip (2001) yang digunakan dalam penelitian ini disesuaikan dengan kebutuhan penelitian seperti pada Gambar 1.

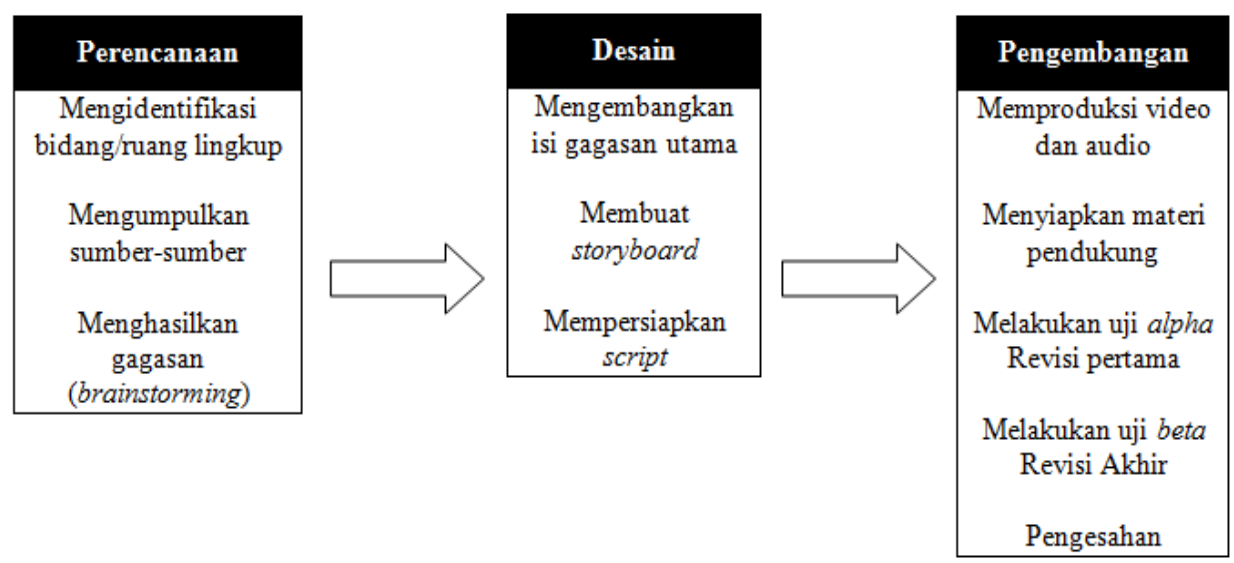

Gambar 1. Model Pengembangan Alessi \& Trollip

Penelitian dan pengembangan ini menggunakan subjek penelitian siswa dalam kelompok kecil. Data yang dihasilkan dalam penelitian ada dua jenis. Data kualitatif yang diperoleh saat pengumpulan data untuk pengembangan video pembelajaran pada tahap perencanaan dengan mengumpulkan sumbersumber, buku pendukung, gambar pendukung dan aplikasi pendukung pengembangan. Data kuantitaif diperoleh dari hasil validasi oleh dosen ahli dan guru matematika serta respon siswa dan hasil tes kemampua penalaran siswa pada materi fungsi komposisi.

Instrument yang digunakan dalam penelitian ini adalah kuisioner dan tes. Kuisioner pertama diberikan kepada dosen ahli dan guru matematika untuk dilakukan validasi pada tahap uji alpha. Kuisioner kedua diberikan kepada siswa untuk mengetahui respon siswa terhadap video pembelajaran yang dikembangkan dan instrument tes diberikan kepada siswa untuk mengukur kelayakan video pembelajaran yang dikembangkan pada tahap uji beta.
Teknik analisis data yang digunakan adalah statistik deskriptif yang berupa pernyataan "sangat setuju", "setuju", "kurang setuju", "tidak setuju" dan "sangat tidak setuju" yang dikonversikan dengan skala likert 1-5. Untuk pengukuran validitas video pembelajaran oleh dosen ahli dan guru matematika, hasil yang diperoleh diinterpretasikan pada kriteria penilaian Tabel 1.

Tabel 1. Kriteria Kevalidan Video Pembelajaran Fungsi Komposisi

\begin{tabular}{cc}
\hline Presentase Pencapaian & Kriteria Kevalidan \\
\hline $80 \% \leq \mathrm{P} \leq 100 \%$ & Sangat Valid \\
\hline $60 \% \leq \mathrm{P}<80 \%$ & Valid \\
\hline $40 \% \leq \mathrm{P}<60 \%$ & CukupValid \\
\hline $20 \% \leq \mathrm{P}<40 \%$ & Kurang Valid \\
\hline $0 \% \leq \mathrm{P}<20 \%$ & Tidak Valid \\
\hline & (Damayanti et.al, 2018)
\end{tabular}

Video pembelajaran fungsi komposisi dikatakan valid jika rata-rata penilaian oleh validator berada pada kriteria "valid" atau "sangat valid" atau mencapai nilai presentase minimal $60,01 \%$. Apabila skor yang diperoleh cukup valid, 
kurang valid ataupun tidak valid akan dilakukan revisi bahan ajar.

Untuk data respon siswa terhadap kelayakan video pembelajaran yang dikembangkan akan dikonversikan dan mengacu pada klasifikasi penilaian pada Tabel 2 .

Tabel 2. Klasifikasi Respon Siswa pada Video Pembelajaran Fungsi Komposisi

\begin{tabular}{|c|c|}
\hline Presentase (N) & Klasifikasi \\
\hline $75 \% \leq \bar{x} \leq 100 \%$ & Sangat Positif \\
\hline $50 \% \leq \bar{x}<75 \%$ & Positif \\
\hline $25 \% \leq \bar{x} \leq 50 \%$ & Negatif \\
\hline $0 \% \leq \bar{x} \leq 25 \%$ & Sangat Negatif \\
\hline & (Yahya \& Bakri, 2017)
\end{tabular}

Video pembelajaran fungsi komposisi dikatakan layak menurut respon siswa jika rata-rata presentase respon positif lebih banyak daripada respon negatif. Apabila respon positif lebih sedikit dari respon negatif maka bahan ajar fungsi komposisi tidak layak digunakan dalam pembelajaran dan akan dilakukan revisi bahan ajar.

Untuk hasil tes yang dilakukan siswa pada materi fungsi komposisi dengan lima indikator kemampuan penalaran matematis, skor yang diperoleh siswa akan dikonversikan dengan pedoman penilaian pada Tabel 3.

Tabel 3. Pedoman Penialaian Tes Kemampuan Penalaran Matematis Siswa

\begin{tabular}{|c|c|c|}
\hline \multicolumn{2}{|c|}{ Nilai } & \multirow{2}{*}{ Kategori } \\
\hline Angka & Huruf & \\
\hline $86-100$ & $\mathrm{~A}$ & Sangat Baik \\
\hline $71-85$ & B & Baik \\
\hline $56-70$ & $\mathrm{C}$ & Cukup \\
\hline $41-55$ & $\mathrm{D}$ & Kurang \\
\hline $0-45$ & $\mathrm{E}$ & Sangat Kurang \\
\hline
\end{tabular}

Dalam penelitian ini, penilaian hasil tes kemampuan penalaran ditentukan dengan nilai yang diperoleh minimal $\mathrm{C}$ atau cukup dalam rentang nilai minimal 56-70. Bermakna bahwa siswa dapat mengerjakan soal yang diberikan dengan menggunaan minimal tiga indikator kemampuan penalaran. Jadi jika rerata hasil tes siswa yang diperoleh adalah $\mathrm{C}$ maka bahan ajar yang dikembangkan layak digunakan untuk pembelajaran fungsi komposisi di SMA/MA.

\section{Hasil dan Pembahasan}

Kurangnya efektifitas pembelajaran saat masa Covid-19 ini dikarenakan kurangnya guru dalam memberikan referensi bahan ajar (Apriansyah \& Pujiastuti, 2020). Dengan menggunakan kreatifitas, dan melihat potensi dari lingkungan, dapat diambil peluang dalam mengembangkan bahan ajar berbentuk video yang kemudian dapat dijadikan alternatif dalam penyampaian pembelajaran. Terlebih pembelajaran disampaikan dengan menggunakan pendekatan konteks kehidupan nyata atau seharihari dapat digunakan sebagai kesempatan guru untuk menstimulus kemampuan penalaran matematis siswa. Kemampuan penalaran dapat dikembangkan apabila guru dapat merangsang siswa untuk bernalar dan memecahkan masalah matematis, selain itu guru dianjurkan untuk memahami karakteristik dari siswa untuk mengembangkan kemampuan penalaran matematis tersebut (Basir, 2015).

Video pembelajaran fungsi komposisi yang dibuat menggunakan software VideoScribe telah melalui tiga tahap pembuatan. Peluang yang didapat dengan mengembangkan video pembelajaran fungsi komposisi memiliki manfaat agar pembelajaran memiliki referensi yang tidak monoton, memberikan pengalaman baru kepada siswa, dan menstimulus siswa untuk berpikir menggunakan kemampuan penalarannya. Dengan sumber-sumber informasi yang mendukung pengembangannya, gagasan dasar dapat dijadikan sebagai acuan dalam produksi video pembelajaran fungsi komposisi.

Dalam penelitian ini data yang diperoleh berasal dari data kualitatif perencanaan dan desain, data kualitatif berupa data uji alpha yang berupa validasi dari dosen ahli dan guru matematika dan data uji beta yang diperoleh dari siswa yang berupa respon dan tes pada materi fungsi komposisi. Dosen ahli dan guru matematika memberikan penilaian validasi sebagai evaluasi dan mengetahui tingkat kelayakan produk yang dikembangkan. Evaluasi produk yang dikembangkan akan diuji cobakan kepada siswa sehingga dapat diketahui respon siswa dan hasil tes siswa terhadap produk yang dikembangkan. Berikut adalah hasil dari 3 fase pengembangan:

\section{a. Perencanaan}

Dalam proses perencanaan diperoleh data kualitatif melalui tahap dimana peneliti mengidentifikasi bidang/ruang lingkup penelitian dengan melakukan observasi. Didapat bahwa dengan pembelajaran yang berlangsung pada masa Covid-19 ini dibutuhkan bahan ajar yang dapat memfasilitasi guru dan siswa dengan pembelajaran jarak jauh. Video pembelajaran merupakan jawaban dari permasalahan tersebut. Selain sebagai alternatif bahan ajar, video pembelajaran juga dapat menarik antusiasme siswa dalam belajar. Setelah melakukan identifikasi, sumber-sumber informasi yang mendukung proses pengembangan 
diikumpulkan sehingga melalui brainstorming didapatkan gagasan dasar. Dari gagasan dasar yang sudah terbentuk kemudian masuk pada selanjutnya.

b. Desain

Pada tahap desain gagasan dasar yang sudah terbentuk kemudian dikembangkan agar memudahkan pengembang dalam memulai proses produksi. Gagasan utama dikembangkan melalui pembuatan storyboard dan script/ narasi.

\section{c. Pengembangan}

Setelah proses persiapan selesai, proses selanjutnya adalah tahap pengembangan. Dimana pada tahap ini dilakukan produksi video pembelajaran fungsi komposisi menggunakan software pendukung yaitu Sparkol VideoScribe sesuai dengan storyboard dan script yang sudah dibuat. Setelah semua scene dibuat dan video akan di render dan kemudian akan dipublikasikan. Untuk publikasi video, dibutuhkan komponen pendukung seperti YouTube sebagai wadah publikasi.

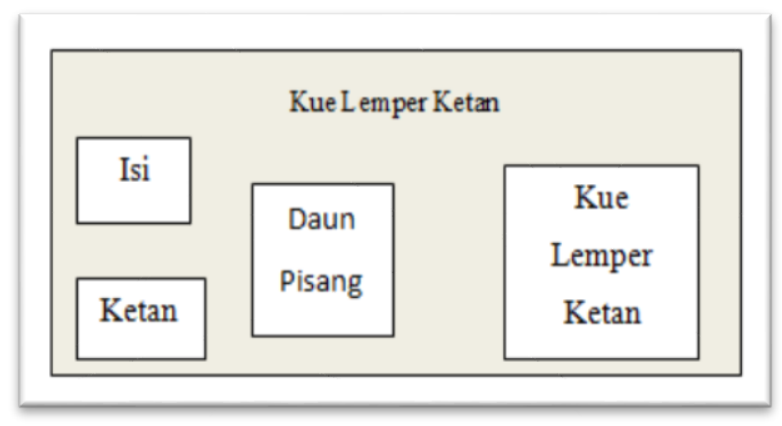

Gambar 2. Scene dalam Storyboard

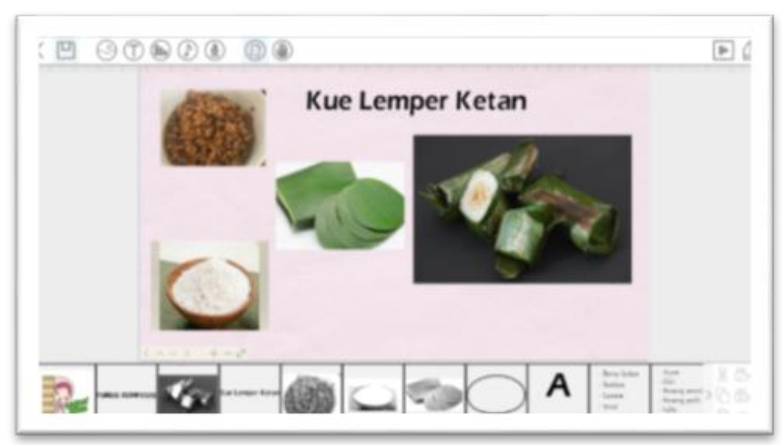

Gambar 3. Scene saat dibuat dengan VideoScribe

Setelah semua scene dalam video dibuat dan dipublikasikan, tahap selanjutnya adalah tahap pengujian. Tahap pertama dalam pengujian video pembelajaran ini adalah uji alpha. Uji alpha merupakan uji awal yang dilakukan oleh dosen ahli dan guru matematika untuk mengetahui kevalidan dan kelayakan bahan ajar yang dikembangkan. Tahapan uji alpha dilakukan oleh ahli materi dan ahli media yang terdiri dari tiga dosen dari program studi Pendidikan Matematika Universitas Sultan
Agung Semarang dan dua guru matematika dari SMA N 14 Semarang. Dalam uji ini dilakukan uji validitas dari aspek materi maupun media untuk mengetahui rasionalitas bahan ajar secara teoritik dan konsistensi komponen isi. Penilaian dilakukan melalui kuisioner yang disajikan melalui aplikasi Google Form. Untuk aspek materi terdapat 10 butir penilaian dan untuk aspek media terdapat 15 butir penilaian yang dapat dilihat pada Tabel 4. Penilaian juga diberikan bersamaan dengan kritik dan saran dari para ahli dan guru matematika sebagai acuan revisi oleh pengembang.

Tabel 4. Kisi-kisi Butir Penilaian

\begin{tabular}{|c|c|c|}
\hline Aspek & Standar Penilaian & $\begin{array}{c}\text { Nomor } \\
\text { Butir }\end{array}$ \\
\hline \multirow{10}{*}{ Materi } & $\begin{array}{l}\text { Isi materi memuat konsep yang } \\
\text { benar sesuai dengan Kompetensi } \\
\text { Dasar dan Tujuan Pembelajaran }\end{array}$ & 1 \\
\hline & $\begin{array}{l}\text { Materi dijabarkan dengan } \\
\text { jelas }\end{array}$ & 2 \\
\hline & Materi tersusun sistematis & 3 \\
\hline & $\begin{array}{l}\text { Materi dikemas untuk } \\
\text { mempermudah siswa dalam } \\
\text { memahami materi }\end{array}$ & 4 \\
\hline & $\begin{array}{l}\text { Kejelasan ilustrasi untuk } \\
\text { memperjelas materi }\end{array}$ & 5 \\
\hline & $\begin{array}{l}\text { Tata bahasa sederhana dan } \\
\text { komunikatif }\end{array}$ & 6 \\
\hline & $\begin{array}{l}\text { Materi memuat konsep } \\
\text { penalaran (reasoning) }\end{array}$ & 7 \\
\hline & $\begin{array}{l}\text { Contoh soal yang dibuat } \\
\text { sesuai dengan isi materi }\end{array}$ & 8 \\
\hline & $\begin{array}{l}\text { Soal-soal latihan mengacu } \\
\text { pada tujuan pembelajaran }\end{array}$ & 9 \\
\hline & $\begin{array}{l}\text { Konsep dan definisi pada } \\
\text { materi bersifat akurat }\end{array}$ & 10 \\
\hline \multirow{10}{*}{ Media } & Kombinasi warna menarik & 1 \\
\hline & $\begin{array}{l}\text { Kesesuaian dari penyajian } \\
\text { gambar dan materi yang } \\
\text { dibahas }\end{array}$ & 2 \\
\hline & Menggunakan & \\
\hline & $\begin{array}{l}\text { Indonesia yang sesuai } \\
\text { dengan Pedoman Umum }\end{array}$ & 3 \\
\hline & $\begin{array}{l}\text { Ejaan Bahasa Indonesia } \\
\text { (PUEBI) }\end{array}$ & \\
\hline & $\begin{array}{l}\text { Kesesuaian bahasa dengan } \\
\text { tingkat berpikir siswa }\end{array}$ & 4 \\
\hline & $\begin{array}{l}\text { Ketepatan teks dengan } \\
\text { materi }\end{array}$ & 5 \\
\hline & 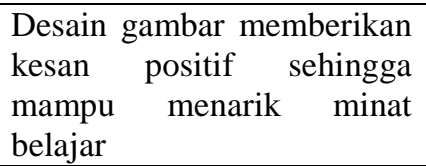 & 6 \\
\hline & $\begin{array}{l}\text { Tipe huruf yang digunakan } \\
\text { terlihat jelas dan terbaca }\end{array}$ & 7 \\
\hline & $\begin{array}{lrr}\text { Penyajian media } & \text { video } \\
\text { mendukung peserta } & \text { didik } \\
\text { untuk terlibat } & \text { dalam } \\
\text { pembelajaran } & \end{array}$ & 8 \\
\hline
\end{tabular}




\begin{tabular}{ll}
$\begin{array}{l}\text { Penyajian media video } \\
\text { dilakukan secara runtut }\end{array}$ & 9 \\
\hline Penyajian gambar menarik & 10 \\
\hline $\begin{array}{l}\text { Animasi/video berhubungan } \\
\text { dengan materi }\end{array}$ & 11 \\
\hline $\begin{array}{l}\text { Suara video yang digunakan } \\
\text { jelas }\end{array}$ & 12 \\
\hline $\begin{array}{l}\text { Antara animasi/video } \\
\text { dengan suara sesuai }\end{array}$ & 13 \\
\hline $\begin{array}{l}\text { Media video mudah } \\
\text { digunakan siswa secara } \\
\text { mandiri tanpa pengawas }\end{array}$ & 14 \\
\hline $\begin{array}{l}\text { Media video dapat } \\
\text { digunakan secara } \\
\text { klasikal/bersama-sama } \\
\text { dikelas }\end{array}$ & 15 \\
\hline
\end{tabular}

Sebelum produk secara resmi digunakan sebagai alternatif bahan ajar. Produk video pembelajaran perlu dilakukan pengujian. Pengujian bermaksud untuk meminimalisir adanya kesalahan sehingga produk bisa diperbaiki. Uji pertama yang dijalankan pada penelitian ini adalah uji alpha. Uji alpha tersebut oleh validator dilakukan dengan menggunakan kuisioner online. Hasil penilaian kevalidan video pembelajaran fungsi komposisi dengan uji alpha dapat dilihat pada Tabel 5.

Tabel 5. Hasil Uji Alpha

\begin{tabular}{crc}
\hline No. & Aspek & \% Kevalidan \\
\hline 1 & Materi & $82,4 \%$ \\
2 & Media & $87,2 \%$ \\
& Rata-rata & $84,8 \%$ \\
\hline
\end{tabular}

Hasil analisis data validasi oleh dosen ahli maupun guru matematika dari aspek materi maupun aspek media masuk dalam kualifikasi "Sangat Valid". Dengan 10 item penilaian materi mendapatkan rerata penilaian sebesar $82,4 \%$. Itu berarti kualitas materi pada bahan ajar yang dikembangkan masuk dalam kriteria "Sangat Valid". Sedangkan pada aspek media dengan 15 item penilaian mendapatkan rerata penilaian sebesar $87,2 \%$. Menandakan bahwa aspek media yang dikembangkan dalam bahan ajar tersebut masuk dalam kriteria "Sangat Valid". Hasil penilaian gabungan antara aspek materi maupun aspek media yang diberikan oleh validator adalah $84,8 \%$ yang mana presentase tersebut masuk dalam kategori "Sangat Valid".

Hasil analisis data yang menunjukkan bahwa kualitas bahan ajar yang dikembangkan "Sangat Valid" menandakan bahwa bahan ajar tersebut layak untuk digunakan dalam pembelajaran di tingkat SMA/MA dengan sedikit revisi. Revisi atau perbaikan dilakukan sesuai dengan masukan dan saran yang diberikan oleh validator agar bahan ajar yang dikembangkan semakin baik dan minim kesalahan.

Uji kedua yang dilakukan pada penelitian ini adalah uji beta. Pada uji ini subjek penelitiannya adalah enam siswa dalam kelompok kecil. Uji beta ini digunakan untuk mengukur kualitas bahan ajar yang dikembangkan dari aspek kemudahan, kemenarikan dan kemanfaatan melalui kuisioner respon. Selain itu, uji beta juga dilakukan untuk melihat kemampuan penalaran matematis siswa dalam menyelesaikan soal tes.

Kuisioner respon siswa berisi 15 pernyataan yang terdiri dari 8 pernyataan positif dan 7 pernyataan negatif. Hasil uji beta berdasarkan respon siswa dapat dilihat pada Tabel 6 .

Tabel 6. Hasil Uji Beta

\begin{tabular}{ccc}
\hline Klasifikasi & Frekuensi & Presentase \\
\hline Sangat Positif & 8 & $80,79 \%$ \\
Positif & 7 & $67 \%$ \\
Negatif & 0 & 0 \\
Sangat Negatif & 0 & 0 \\
Rata-rata & & $74 \%$ \\
\hline
\end{tabular}

Berdasarkan pada Tabel 6 didapat dari 15 item penilaian, 7 item penilaian mendapat respon "positif" dan 8 item mendapat respon "sangat positif". Secara keseluruhan rerata respon yang didapat dari siswa adalah $70 \%$ yang berarti "positif". Sesuai dengan kriteria kelayakan bahan ajar yang dikembangkan yaitu rerata respon positif lebih banyak daripada respon negatif maka dapat dinyatakan bahwa bahan ajar yang dikembangkan memiliki kemudahan, kemenarikan, kemanfaatan dan layak digunakan dalam proses pembelajaran.

Selain hasil respon siswa, uji beta juga dilakukan untuk melihat kemampuan penalaran matematis siswa pada materi fungsi komposisi yang disajikan melalui video pembelajaran maka dilakukan tes dengan soal uraian. Dan didapat hasil seperti pada Tabel 7 .

Tabel 7. Hasil Tes Kemampuan Penalaran Matematis Siswa

\begin{tabular}{ccccc}
\hline No & $\begin{array}{c}\text { Kode } \\
\text { Siswa }\end{array}$ & $\begin{array}{c}\text { Total } \\
\text { Skor }\end{array}$ & Nilai & Kategori \\
\hline 1 & ZHF & 66 & C & Baik \\
\hline 2 & NLA & 73 & B & Baik \\
\hline 3 & MNS & 60 & C & Cukup \\
\hline 4 & MAA & 73 & B & Baik \\
\hline 5 & PMC & 73 & B & Baik \\
\hline 6 & EPJ & 73 & B & Baik \\
\hline \multicolumn{2}{r}{ Rata-rata } & 69,6 & C & Cukup \\
\hline
\end{tabular}

Tabel 7 menunjukkan bahwa hasil tes kemampuan penalaran matematis siswa pada materi fungsi komposisi yang disajikan melalui 
video pembelajaran masuk dalam kategori cukup dengan rerata skor 69,6 dari 100. Skor tersebut berada pada skor minimal yang ditetapkan pada penelitian ini. Berdasarkan data yang sudah disajikan, 4 siswa memperoleh nilai B atau "baik" dan 2 siswa memperoleh nilai "C" atau cukup. Sesuai dengan kriteria kelayakan bahan ajar dari hasil tes yang dilakukan dengan rerata minimal $\mathrm{C}$ atau cukup, bahan ajar yang dikembangkan layak digunakan dalam pembelajaran fungsi komposisi di SMA/MA.

\section{Kesimpulan}

Berdasarkan penelitian dan pengembangan, didapat video pembelajaran fungsi komposisi berbantuan videoscribe sebagai alternatif bahan ajar dengan kemampuan penalaran matematis. Dilakukan pengujian melalui dua uji untuk mendapatkan penilaian kelayakan bahan ajar tersebut agar dapat digunakan pada proses pembelajaran.

Dengan mendapatkan penilaian oleh validator sebesar $84,8 \%$ dari aspek materi dan media. Serta penilaian $70 \%$ positif dari siswa dan hasil tes yang berada pada standar minimal yaitu 69,6 dari 100 maka video pembelajaran fungsi komposisi berbantuan videoscribe sebagai alternatif bahan ajar dengan kemampuan penalaran matematis layak digunakan sebagai bahan ajar dalam proses pemebelajaran di tingkat SMA/MA.

Pada penelitian ini, penulis menyarankan bahwa video pembelajaran yang telah dikembangkan dapat digunakan dalam proses pembelajaran online pada masa Covid-19 sebagai alternatif bahan ajar maupun pada pembelajaran di kelas secara langsung. Selain itu, disarankan untuk penelitian selanjutnya menguji efektivitas penggunaan video pembelajaran tersebut dengan banyak subyek penelitian.

\section{Daftar Pustaka}

Akbar, R. R. A., \& Komarudin, K. (2018). Pengembangan Video Pembelajaran Matematika Berbantuan Media Sosial Instagram sebagai Alternatif Pembelajaran. Desimal: Jurnal Matematika, $1(2), \quad 209$. https://doi.org/10.24042/djm.v1i2.2343

Alessi, S. ., \& Trollip, S. (2001). Multimedia for learning: mehods and development (3rd Edition) (3rd ed.). Allyn and Bacon.

Apriansyah, M. F., \& Pujiastuti, H. (2020). Pengembangan Bahan Ajar Matematika berbasis Virtual Learning dengan Gnomio. Jurnal
Pendidikan Matematika, 11(2), 179-188. https://doi.org/http://dx.doi.org/10.36709/jpm.v $11 \mathrm{i} 2.11921$

Arfianto, H., \& Hakim, D. L. (2019). Penalaran Matematis Siswa Pada Materi Fungsi. Prosiding Seminar Nasional Matematika Dan Pendidikan Matematik Sesiomadika 2019, 2018, 1248-1256.

Basir, M. A. (2015). Masalah Matematis Ditinjau Dari Gaya Kognitif. Jurnal Pendidikan Matematika FKIP Unissula, 3(1), 106-114.

Damayanti et.al. (2018). Kelayakan Media Pembelajaran Fisika Berupa Buku Saku Android pada Materi Fluida Statis. Indonesian Journal of Science and Matematics Education, 1(1), 63-70.

Fuadi, R., Johar, R., \& Munzir, S. (2016). Peningkatkan Kemampuan Pemahaman dan Penalaran Matematis melalui Pendekatan Kontekstual. Jurnal Didaktik Matematika, 3(1), 47-54. https://doi.org/10.24815/jdm.v3i1.4305

Kusumawati, E., \& Aulia, F. (2018). Identifikasi Kesulitan Menyelesaikan Soal Fungsi Komposisi Peserta Didik Kelas X Keuangan Smk Negeri Di Banjarmasin Tahun Pelajaran 2016/2017. EDUMAT: Jurnal Pendidikan Matematika, 5(2), 150 161. https://doi.org/10.20527/edumat.v5i2.4639

Lopes, A. P., \& Soares, F. (2016). Video Lectures and Online Activities To Engage Students in a Flipped Classroom. EDULEARN16 Proceedings, 1(July), 8688-8695. https://doi.org/10.21125/edulearn.2016.0890

Muslimin, \& Sunardi. (2019). Analisis Kemampuan Penalaran Matematika Siswa SMA pada Materi Geometri Ruang. KREANO : Jurnal Matematika Kreatif Dan Inovatif, 10(2), 171-178. https://doi.org/https://doi.org/10.15294/kreano.v $10 \mathrm{i} 2.18323$

Perlman, S. (2020). Another Decade, Another Coronavirus. New England Journal of Medicine, 382(8), https://doi.org/10.1056/NEJMe1917479

Purwanto, Y., \& Rizki, S. (2015). Pengembangan Bahan Ajar Berbasis Kontekstual Pada Materi Himpunan Berbantu Video Pembelajaran. AKSIOMA Journal of Mathematics Education, 4(1),

$67-77$ https://doi.org/10.24127/ajpm.v4i1.95

Rifai, A. S. (2016). Analisis kesulitan siswa belajar matematika pada pokok bahasan komposisi fungsi dan invers fungsi kelas xi sma negeri 8 bulukumba kabupaten bulukumba. http://repositori.uinalauddin.ac.id/11324/1/SKRIPSI SYAMSUL RIFAI.pdf

ANDI

Susanti, B., \& Lestari, Y. A. P. (2019). Analisis Kesulitan Siswa Kelas XI dalam Menyelesaikan Soal Fungsi Komposisi Dan Fungsi Invers di SMK AL-IKHSAN Batujajar. Journal on Education, 01(03), 446-459. http://www.jonedu.org/index.php/joe/article/vie w/189/158

Thomas, C. (1997). The composite function rule ( the chain rule ) [University of Sidney]. In Mathematics Learning Centre. 
https://www.sydney.edu.au/content/dam/student s/documents/mathematics-learningcentre/composite-functions-and-derivatives.pdf

Utami, A. S. (2017). Analisis kesalahan siswa dalam menyelesaikan soal cerita pokok bahasan komposisi fungsi di SMK Bakti Purwokerto. Journal of Mathematics Education, 3(2), 48-56.

Wardoyo, T. C. T., \& Faqih Ma'arif, M. (2015). Pengembangan Media Pembelajaran Berbasis Video Animasi Pada Mata Pelajaran Mekanika Teknik Di SMK Negeri 1 Purworejo. E-Journal Pend. Teknik Sipil Dan Perencanaan, 3(3), 1. http://journal.student.uny.ac.id/ojs/index.php/sip il/article/view/4171

Weeraratne, B., \& Chin, B. (2018). Can Khan Academy e-Learning Video Tutorials Improve Mathematics Achievement in Sri Lanka? International Journal of Education and Development Using Information and Communication Technology, 14(3), 93-112.

Yahya, A., \& Bakri, N. W. (2017). Penerapan Model Kooperatif Student Teams Achievement Divisions untuk Meningkatkan Hasil Belajar Siswa. JURNAL SAINTIFIK, 3(2), 171-181. https://doi.org/10.26675/jabe.v1i4.6035 